\title{
Carreira: novos rumos e desafios
}

M

undo intrigante, esse nosso. Travase intenso debate sobre o rumo das economias e sobre os benefícios e malefícios do processo de globalização dos mercados e, curiosamente, a discussão estanca aí. Enquanto isso, no ambiente empresarial, ocorre uma verdadeira revolução que, para muitos, permanece oculta, a despeito de ter começado há pelo menos uma década. Falamos da reviravolta experimentada pela condição humana no trabalho. Imagine-se, para citar apenas dois exemplos extremos, o mineiro de carvão do Peru, que vê a automação liquidar definitivamente seu emprego, e o alto executivo em um suntuoso edifício da marginal do rio Pinheiros, na capital paulista, que vê sua carreira ameaçada por um processo de fusão ou aquisição, mesmo que seu desempenho anterior sugerisse uma perspectiva otimista.

Nesta coluna, inaugurada na presente edição da RAE-executivo, vamos aprofundar esse tema e, principalmente, aportar contribuições para o encaminhamento prático das questões a ele relacionadas. Procuraremos também indicar caminhos para reduzir os impactos negativos desses fenômenos, tão dramáticos quanto inevitáveis.

Neste primeiro momento, buscamos apenas situar o fenômeno e sua relevância. Nos próximos números, vamos tratar do papel dos presidentes de empresa, bem como da atuação dos gestores de Recursos Humanos, na gestão Vicky Bloch dos impactos causados sobre os indivíduos por DBM do Brasil tais mudanças. Finalmente, vamos indicar caminhos que atendam às necessidades dos indivíduos que sofrem as conseqüências negativas dos citados movimentos

O fato é que o Brasil abriu a decisiva década de 1990 com seus quadros gerenciais despreparados para as exigências de eficiência e eficácia derivadas do processo de inserção do país na ordem econômica mundial. Vínhamos de uma realidade com baixo nível de exigência, caracterizada por mercados protegidos, traços de culturas oligárquicas e o velho hábito de ganhar dinheiro sem grande preocupação com o fator competitividade.

A partir da abertura de mercado, veio uma situação quase caótica. As mudanças somaramse. Agora, superada a fase de ajustes, percebe-se que o mundo não é e não voltará a ser o mesmo.

Gerir pessoas, gerir mudanças e, notadamente, gerir pessoas sujeitas a mudanças, são os desafios que passaram a integrar a agenda dos dirigentes empresariais e de seus assessores. Desafio ainda maior é o desenvolvimento de uma nova postura dos profissionais envolvidos em mudanças, que, até agora, praticamente só perceberam no fenômeno o tamanho do rolo compressor, assumindo um papel passivo, de vítima indefesa.

A ocasião agora é de agir com iniciativa e criatividade. O momento de mudança continua a apresentar desafios e riscos para as empresas e seus profissionais, mas também apresenta inúmeras oportunidades. 